\title{
Variations of Movement, Dispersal, and Morphometrics among Subpopulations of Javan Endemic Damselfly, Drepanosticta spatulifera (Odonata: Platystictidae) in Petungkriyono Forest
}

\author{
Amelia Nugrahaningrum ${ }^{1}$, R.C. Hidayat Soesilohadi ${ }^{1 *}$ \\ 1) Faculty of Biology, Universitas Gadjah Mada, Teknika Selatan Street, Senolowo, Sinduadi, Mlati, Sleman, Yogyakarta 55281 \\ * Corresponding author, email: hidayat@ugm.ac.id
}

Submitted: 01 May 2021; Accepted: 27 June 2021; Published online: 06 September 2021

\begin{abstract}
Drepanosticta spatulifera is a Javan endemic damselfly. The population is spread unevenly in the Petungkriyono Forest and is threatened due to environmental pressure. The aims of this research are to know the variation of the movement, dispersal, and morphometric among subpopulations of D. spatulifera. Movement and dispersal variation data collection was done using Mark Release Recapture (MRR) for six weeks from early August until mid-September 2020. The collection of morphometric samples was done during the last week of the MRR survey and 46 individuals were measured with 12 continuous characters. During the MRR survey, 596 males of D. spatulifera were marked and 302 were recaptured. D. spatulifera had short movement and dispersal thus no individuals were found across the subpopulations. The distance moved of successive capture and net lifetime movement were dominantly less or equal to five meters. The duration of the MRR survey had a low correlation with the dispersal distance of $D$. spatulifera. In the morphometric variations, closer subpopulations tended to have a similar cluster of morphometric characters. Variation of distance moved between successive capture and wing size from Mangli Stream was significantly different from other sites. The subpopulation of Mangli, the farthest and higher altitude of the sites, had the highest distance move, more disperse, and the largest wing size. Our study showed that $D$. spatulifera was extremely sedentary damselfly. It will enhance inbreeding and vulnerability to extinction. Therefore, the interaction between the subpopulations of $D$. spatulifera in the Petungkriyono Forest needs to be done more.
\end{abstract}

Keywords: Drepanosticta, damselfly, dispersal, morphometrics, variation

\section{INTRODUCTION}

Variation is a crucial case for adaptation and evolution. Variation within species is referred to as intraspecific variation (O'Dell \& Rajakaruna 2011). Intraspecific variation emerges from the local population or metapopulation (Hanski 2008). Intraspecific variation will maintain the resilience and persistence level of the population. Several forms of intraspecific variation can be explained with movement, dispersal, and morphometric studies (Gyulavári et al. 2011; Dolný et al. 2014; Gibert 2016). 
Movement and dispersal variation contribute to rescue effect, colonization, population turnover, and extinction (Hanski 2008). Movement and dispersal give an impact on gene flow then influence the genetic variation and phenotype appearances. Morphometry is a form of phenotype appearance. Previous studies examining the flight ability of Odonata suggested that morphometrics such as wings size and thorax size are potential to affect their flight performance. Flight performance will affect the movement and dispersal behaviour (McCauley 2013).

Drepanosticta spatulifera is one of the Javan endemic damselflies from the Zygoptera Order (Lieftinck 1929). The distribution of Drepanosticta is restricted in Asian tropical forests (van Tol 2009). Species of Drepanosticta are usually endemic to the island and have poor flight ability (Kalkman \& Orr 2013) likewise D. spatulifera which is endemic to Central Java. D. spatulifera is only distributed in Slamet Mountain, Ungaran Mountain, and Petungkriyono Forest. Based on previous studies, D. spatulifera is a sensitive species, inhabits a small niche, and small population (Diniarsih 2016; Nugrahaningrum 2018; Zaman et al. 2019). These characters are population characteristics that are vulnerable to extinction (Suhonen et al. 2010).

D. spatulifera is more abundant in the Petungkriyono Forest than Slamet Mountain and Ungaran Mountain (Diniarsih 2016; Nugrahaningrum 2018; Zaman et al. 2019). Based on the observation, adult D. spatulifera in Petungkriyono Forest appeared throughout the year. Although D. spatulifera in Petungkriyono Forest is easier to find, their habitat is uneven and threatened by land conversion. Therefore, it is important to study the intraspecific variation of $D$. spatulifera in Petungkriyono Forest. The effort will inform their survival in patchy habitat and help the conservation management of $D$. spatulifera. In line with that, this study aims to study the variation of movement, dispersal, and morphometrics of $D$. spatulifera subpopulation in Petungkriyono Forest.

\section{MATERIALS AND METHODS}

\section{Study Species}

D. spatulifera is a member of the family Platystictidae (Lieftinck 1929). The members of the family Platystictidae inhabit deep forests with dense vegetation near a stream. The species is well known as the percher damselfly (van Tol 2009) and the information about it is limited. Based on the IUCN Red List, the status of D. spatulifera is Data Deficient (Dow 2009).

$D$. spatulifera is an endemic Java damselfly. Recently, D. spatulifera is only found on the slopes of Mount Slamet, Ungaran Mountain, and Petungkriyono Protected Forest (Diniarsih 2016; Nugrahaningrum 2018; Zaman et al. 2019). Its body size is smaller than other Genera Drepanosticta in Java. The length of the male abdomen is about $29 \mathrm{~mm}$ and the length of the hindwing is approximately $20.5 \mathrm{~mm}$. Male $D$. spatulifera have a completely black synthorax, brownish-black abdomen with small yellowish-brown rings on segments 3 to 7 , the distal segment 8 is sky-blue, similar to segments 9 and 10 . Female $D$. spatulifera have the same synthorax and abdomen segments $1-7$ as that of the male, while segment 8 on the dorsum is blue, and segments 9 and 10 are black (Lieftinck 1929). Figure 1 shows the picture of D. spatulifera.

\section{Study Sites}

The study area was located in Petungkriyono Forest, Pekalongan, Central Java. D. spatulifera was found mainly on small streams with dense vegetation in the site. Based on the field survey in Januari, 2020, D. spatulifera were found in nine streams; namely Bido (BD), Bancet (BC), Cakrawakti (CK), 

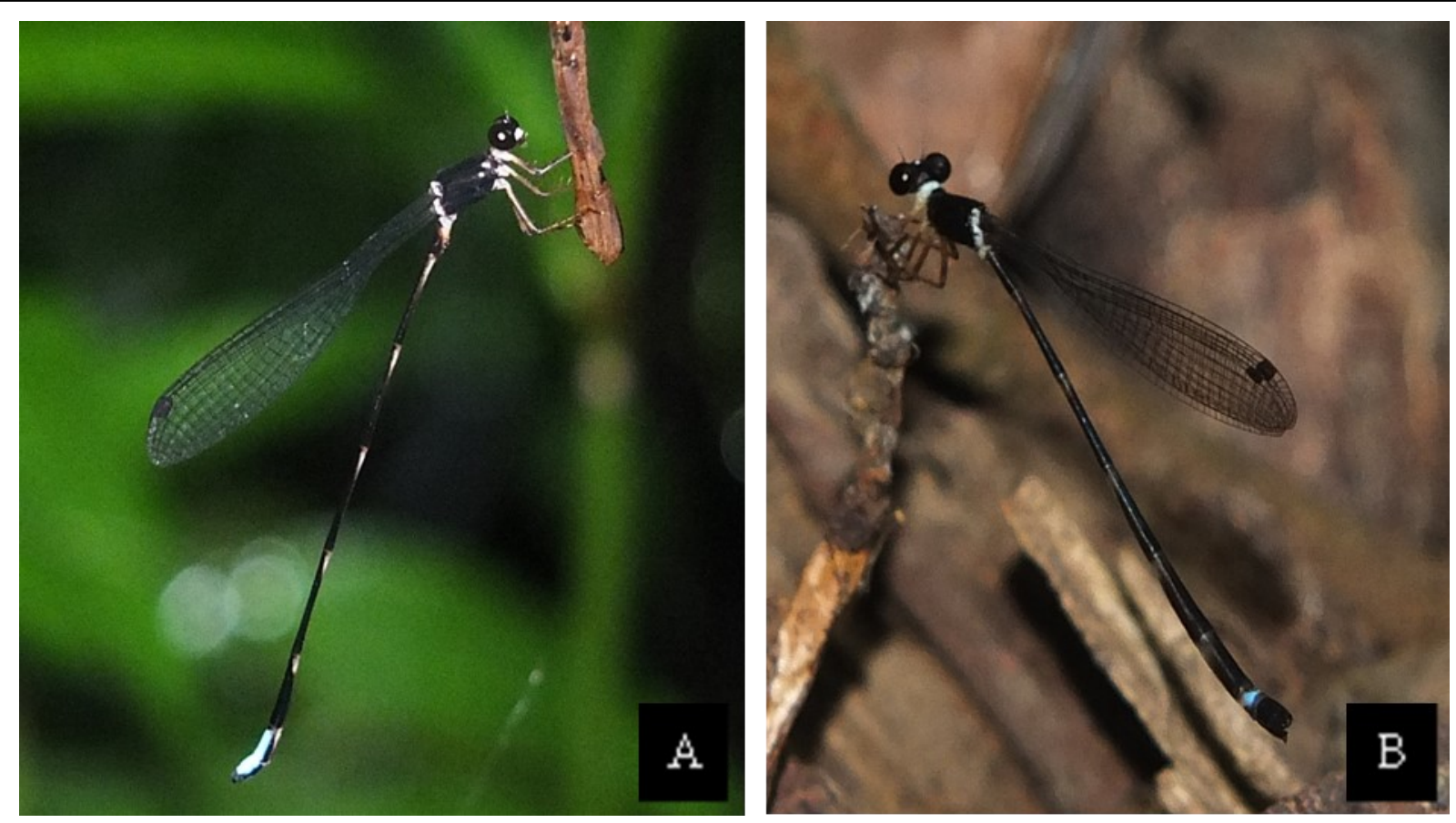

Figure 1. (A) Male and (B) Female D. spatulifera in Petungkriyono Forest (C) Amelia Nugrahaningrum.

Mangli (MG), Sokokembang 1 (SK.1), Sokokembang 2 (SK.2), Sokokembang 3 (SK.3), Sepingit (SP), and Srenggi (SR) (Figure 2). Environmental factors at the nine locations were measured (Table 1). However, MRR studies and morphometric sampling of D. spatulifera could be performed only in Bido, Sokokembang 1, Sokokembang 2, Sokokembang 3, and Mangli stream because of the high number of $D$. spatulifera in these locations during AugustSeptember 2020.

\section{Mark Release Recapture (MRR) Survey}

Mark Release Recapture (Rouquette \& Thompson 2007; Hassall \& Thompson 2012) was conducted from August 8, 2020, to September 19, 2020. All sites were sampled from approximately 9 A.M to 4 P.M for six weeks. The capture and marking of D. spatulifera were done on each river with a length of $100 \mathrm{~m}$ and a width of $4 \mathrm{~m}$. Recapturing was done with a length of $300 \mathrm{~m}$ and a width of $4 \mathrm{~m}$ for each stream except in Sokokembang 1 where the data was only collected along $50 \mathrm{~m}$ length and $4 \mathrm{~m}$ width due to the steep stream.

The aerial net was used to catch $D$. spatulifera. The captured individuals were marked on the thorax using V-Tec paint-based oil and V-Tec round

Table 1. Coordinate locations and environmental factors of the nine sampling sites during August-September 2020.

\begin{tabular}{|c|c|c|c|c|c|c|c|c|}
\hline \multirow[t]{2}{*}{ Loc. } & \multirow{2}{*}{$\begin{array}{l}\text { Coordinate } \\
\text { Loc. }\end{array}$} & \multirow{2}{*}{$\begin{array}{l}\text { Alt. } \\
\text { (m asl) }\end{array}$} & \multirow{2}{*}{$\begin{array}{l}\text { Herbaceous } \\
\text { Vegetation } \\
\text { Cover }(\%)\end{array}$} & \multirow{2}{*}{$\begin{array}{l}\text { Total } \\
\text { Vegetation } \\
\text { Cover }(\%)\end{array}$} & \multicolumn{2}{|c|}{$\begin{array}{l}\text { Air Temp. } \\
\left({ }^{\circ} \mathrm{C}\right)\end{array}$} & \multicolumn{2}{|c|}{$\begin{array}{l}\text { Humidity } \\
(\%)\end{array}$} \\
\hline & & & & & mean & sd & mean & $\mathrm{sd}$ \\
\hline $\mathrm{BD}$ & S $07^{\circ} 04.433^{\prime}$ E $109^{\circ} 43.377^{\prime}$ & 528 & 51.14 & 89.42 & 26.16 & 3.30 & 90.57 & 6.79 \\
\hline SP & $\mathrm{S} 07^{\circ} 05.064^{\prime} \mathrm{E} 109^{\circ} 43.411^{\prime}$ & 509 & 33.83 & 78.30 & 24.59 & 1.36 & 94.40 & 4.05 \\
\hline SK.3 & $\mathrm{S} 07^{\circ} 05.160^{\prime} \mathrm{E} 109^{\circ} 43.380^{\prime}$ & 517 & 49.76 & 94.26 & 24.97 & 2.46 & 94.64 & 4.29 \\
\hline SK.2 & S $07^{\circ} 05.338^{\prime} \mathrm{E} 109^{\circ} 43.412^{\prime}$ & 522 & 51.35 & 92.89 & 27.28 & 3.28 & 86.86 & 7.46 \\
\hline SK.1 & $\mathrm{S} 07^{\circ} 05.721^{\prime} \mathrm{E} 109^{\circ} 43.481^{\prime}$ & 532 & 51.03 & 92.09 & 25.20 & 1.34 & 96.44 & 3.77 \\
\hline SR & S $07^{\circ} 08.854^{\prime} \mathrm{E} 109^{\circ} 42.369^{\prime}$ & 817 & 23.80 & 72.68 & 26.86 & 3.03 & 80.00 & 10.18 \\
\hline $\mathrm{BC}$ & S $07^{\circ} 08.749^{\prime}$ E $109^{\circ} 42.229^{\prime}$ & 831 & 58.90 & 93.20 & 26.72 & 1.64 & 80.39 & 7.33 \\
\hline MG & $\mathrm{S} 07^{\circ} 08.739^{\prime} \mathrm{E} 109^{\circ} 42.177^{\prime}$ & 859 & 45.28 & 92.94 & 24.71 & 1.54 & 86.59 & 6.74 \\
\hline CK & S $07^{\circ} 08.119^{\prime}$ E $109^{\circ} 43.934^{\prime}$ & 1190 & 22.35 & 87.80 & 26.21 & 1.95 & 73.99 & 10.48 \\
\hline
\end{tabular}




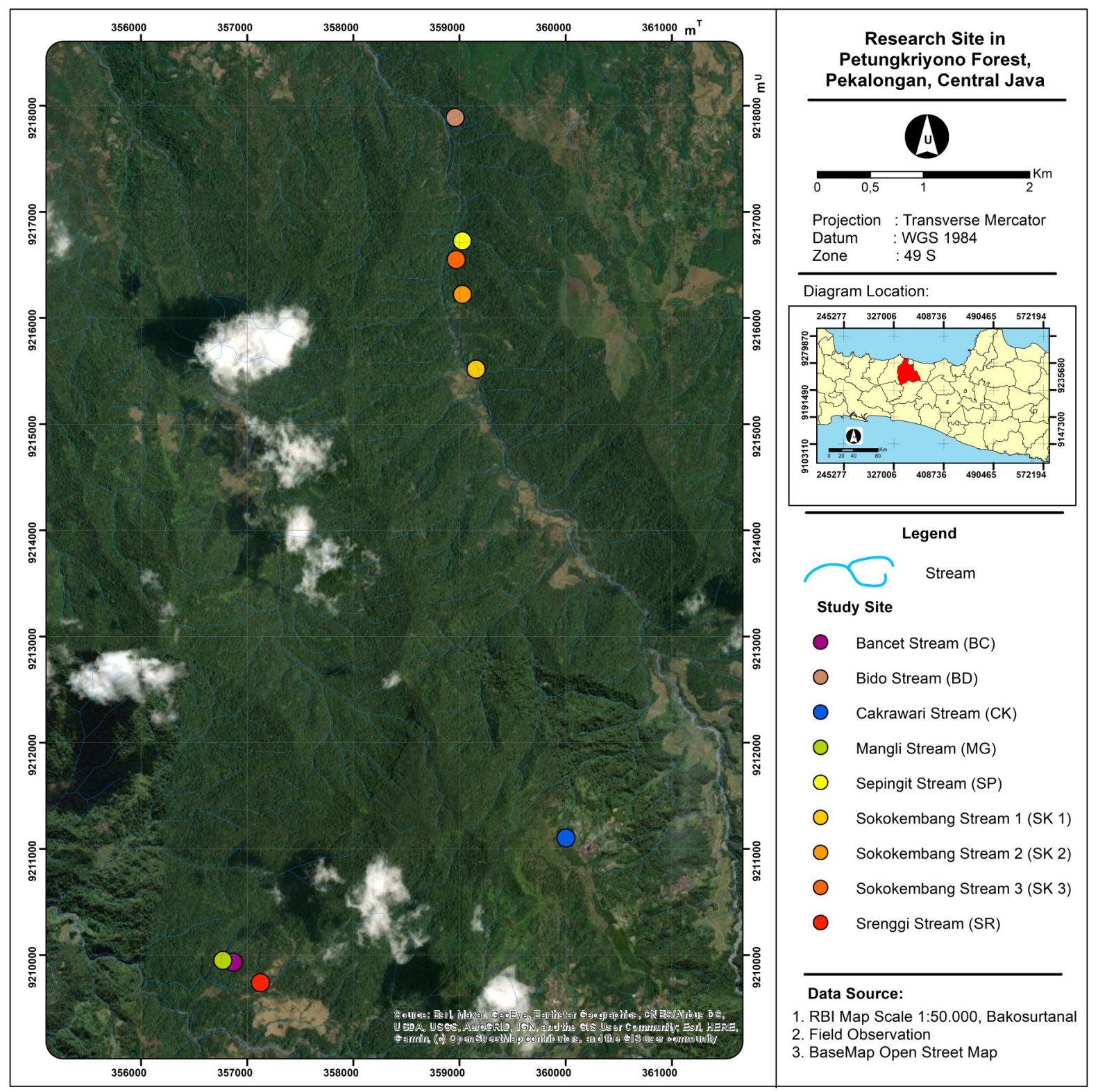

Figure 2. The Map of Study Site of D. spatulifera in Petungkriyono, Pekalongan.

brush with a unique code. Unique codes were drawn by colour and shape variation (dot and line). Afterwards, the perch points of the captured individuals were tagged by a ribbon and paper tape. Information about the date, time, and unique code had been written on the paper tape.

Furthermore, the captured individuals were released. The process of capturing and marking individuals was done at weeks 0 to 5 .

Individual recaptures were done from the 1 st to the 6 th week. The perch points of the recaptured individuals were tagged by a ribbon and paper tape. Information about the date, time, recapture frequency, and unique code was written on the paper tape. The Euclidean distance between the perch points of the recaptured and previous capture of each individual was measured by roll meter and recorded. The distance value was called as $\mathrm{d}$ value. On the 6th week, the Euclidean distance between the first and last capture of each individual was measured as a net lifetime movement or $\mathrm{L}$ value.

\section{Morphometric Measurement}

Morphometric samples of individuals were randomly selected from the MRR study in the 6th week (13th-19th September 2020). Specimens from the field 
were preserved in ethanol $96 \%$. In total, 46 individuals of $D$. spatulifera were measured. Individual details are presented in Table 2. Twelve continuous characters were measured using Supereyes B011. These characters consist of the total length of the body (BL), abdomen (AL), right of fore and hind wings (RFw, RHw), width of the head (HW), labrum (LW), distance between the compound eyes (CED), distance between scapes (ASD), distance between nodus and pterostigma on the right wings (RFwNP, rHwNP) (Gyulavári et al. 2011), length of cerci (CL), and length of paraproct (PL). Measurement activities were carried out in November 2020 at the Entomology Laboratory of Biology Faculty, Universitas Gadjah Mada.

Table 2. Number of morphometric individuals of D. spatulifera.

\begin{tabular}{cc}
\hline Site & $\mathrm{n}$ \\
\hline BD & 10 \\
MG & 10 \\
SK.1 & 6 \\
SK.2 & 10 \\
SK.3 & 10 \\
All Site & 46 \\
\hline
\end{tabular}

\section{Statistical Analysis}

The total number of marked individuals, the total number of recaptured individuals, and the percentage of moved and non-moved individuals were calculated. Due to the low movement and dispersal, its value was categorized every five meters. All calculations were done using Microsoft Excel 2019. Parameters information about the data movement and dispersal were arranged in Table 3. This study chose the Kruskal-Wallis and Pairwise Wilcox Test with the Benjamini-Hochberg method to analyse the parameters of movement and dispersal variation. Boxplot was used to compare $\mathrm{d}$ values and $L$ values between the sites. A scatterplot was used to visualize the mean of $\mathrm{d}$ value and the cumulative distance moved (D) between weeks and sites. We used One Way ANOVA and Post Hoc Duncan Multiple Rank Test to calculate the level of significant differences of morphometric variations between subpopulations. Semi-supervised Local Fischer Discriminant Analysis (SELF) was used to visualize the group of morphometric variation between the sites. Kendall correlation was used to measure the correlation between wing size and dispersal. All analyses were performed using R Studio version 4.0.3.

Table 3. Parameter of movement and dispersal variation (Rouquette \& Thompson 2007).

\begin{tabular}{ll}
\hline Parameter & Definition \\
\hline $\mathrm{d}$ & Distance moved between successive capture for each individual (m) \\
$\mathrm{D}$ & Cumulative distance moved (m); sum of $d$ for each individual \\
$\mathrm{L}$ & $\begin{array}{l}\text { Net lifetime movement (m); distance between the first and last } \\
\text { capture }\end{array}$ \\
\hline
\end{tabular}

\section{RESULTS AND DISCUSSION}

\section{Number of Marks and Recaptures}

Mark Release Recapture (MRR) was only done in five sites or subpopulations considering the abundance of D. spatulifera. They were Bido, Mangli, 
Sokokembang 1, Sokokembang 2, and Sokokembang 3. On the other side, only one individual of D. spatulifera existed at Sepingit Stream and Bancet Stream on the first week and sixth week. Afterwards, D. spatulifera was absent at Srenggi Stream dan Cakrawati Stream due to the lowest canopy cover and the lowest humidity (Table 1).

Table 4. Number of Marked and Recaptured Individuals of D. spatulifera during MRR Survey.

\begin{tabular}{ccccc}
\hline \multirow{2}{*}{ Site } & \multirow{2}{*}{ Marked } & \multicolumn{3}{c}{ Recaptured } \\
\cline { 3 - 5 } & & Individuals & Percentage & Events \\
\hline BD & 176 & 92 & 52.27 & 150 \\
MG & 57 & 34 & 59.65 & 51 \\
SK.1 & 31 & 19 & 61.29 & 35 \\
SK.2 & 145 & 74 & 51.04 & 105 \\
SK.3 & 187 & 83 & 44.39 & 133 \\
All Sites & 596 & 302 & 50.67 & 474 \\
\hline
\end{tabular}

In total, 596 D. spatulifera were marked. Of these, 302 individuals were recaptured at least once through 474 recapture events. The percentage of recaptured was high, namely $50.67 \%$ (Table 4). Short movement behaviour is one of the factors of high recapture. Compared to another study on damselflies dispersal, such as Coenagrion mercuriale, the percentage of recapture during MRR only achieved 29\% (Rouquette \& Thompson 2007), 48\% (Keller \& Holderegger 2013), and 24.7\% (La Porta \& Goretti 2020). The maximum recaptured frequency was five times. The interval times between the first and last capture varied. The longest time between the first and last capture was six weeks or 42 days. The highest marked and recaptured individuals were at Bido Streams and the lowest was at Sokokembang 1.

All individuals of MRR were male. Male D. spatulifera were easier to observe than females. Most of the time, male $D$. spatulifera merely perched under a canopy. No female individuals were marked during the MRR survey due to the low encounters. Female D. spatulifera perched far from the stream or breeding site. Sometimes, female D. spatulifera were observed outside the transect and perched on herbaceous trees or tall branches. Dolný et al. (2014) and Zebsa et al. (2015) mentioned that female damselflies will close the stream or breeding site when they are ready to mate and lay eggs. Teneral of D. spatulifera was also not observed during the MRR survey since it was still fragile and very risky to handle. Rouquette \& Thompson (2007) explained that there was no significant difference between the movement behavior of teneral and adult Odonata.

\section{Variation of Movement and Dispersal}

The variation of movement and dispersal were shown by the value of distance moved between successive capture for each individual (d), cumulative distance moved (D), and net lifetime movement $(\mathrm{L})$. The mean distance moved between successive capture for each individual (mean d) was low. The farthest mean $\mathrm{d}$ was only reached $85.11 \mathrm{~m}$. The distance of mean $\mathrm{d}$ dominantly was less or equal to $5 \mathrm{~m}(81.12 \%)$. The mean $\mathrm{d}$ that occurs more than $10 \mathrm{~m}$ seems like outlier data (Figure 3).

There was no single individual of $D$. spatulifera who migrated to another stream during the MRR survey. Individual movements were only observed along the water body of the stream. This pattern is similar to C. mercuriale in Clitunno River, Italia (La Porta \& Goretti 2020) and is classified as a short- 
distance movement. They only explored or traveled through the surrounding habitat (Ramakrishnan 2018). Probably, D. spatulifera has long-distance behavior. However, long-distance movement of damselflies is hardly observed directly in the field (Keller \& Holderegger 2013).

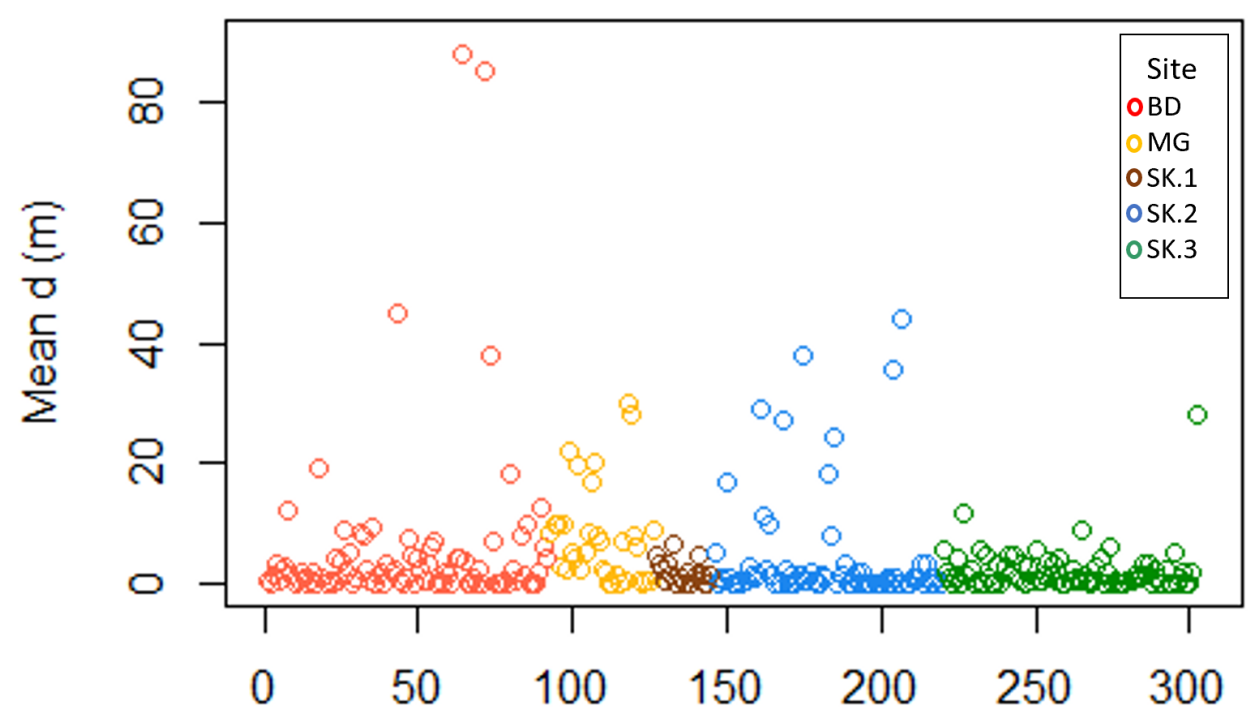

Number of Recaptured Individual

Figure 3. Variation mean d value of $D$. spatulifera individual recaptured between five subpopulations, BD (Bido), MG (Mangli), SK.1 (Sokokembang 1), SK.2

(Sokokembang 2), and SK.3 (Sokembang 3). In total 81,12\% individuals had mean d $\leq 5 \mathrm{~m} ; 10,60 \%$ individuals had $5<$ mean $\mathrm{d} \leq 10 \mathrm{~m}$; and $8,28 \%$ had mean $\mathrm{d}>10 \mathrm{~m}$.

Drepanosticta genera are commonly known to have poor flight behavior. Its behavior encourages Drepanosticta to become an endemic species to the island (van Tol 2009). D. spatulifera in Petungkriyono Forest was an extremely sedentary species. Commonly, it perches at the same twig, branch, or leaf between successive capture. Based on the total number of recapture events (474), $66.03 \%$ moved and $33.97 \%$ stayed at the same perch point as the previous week.

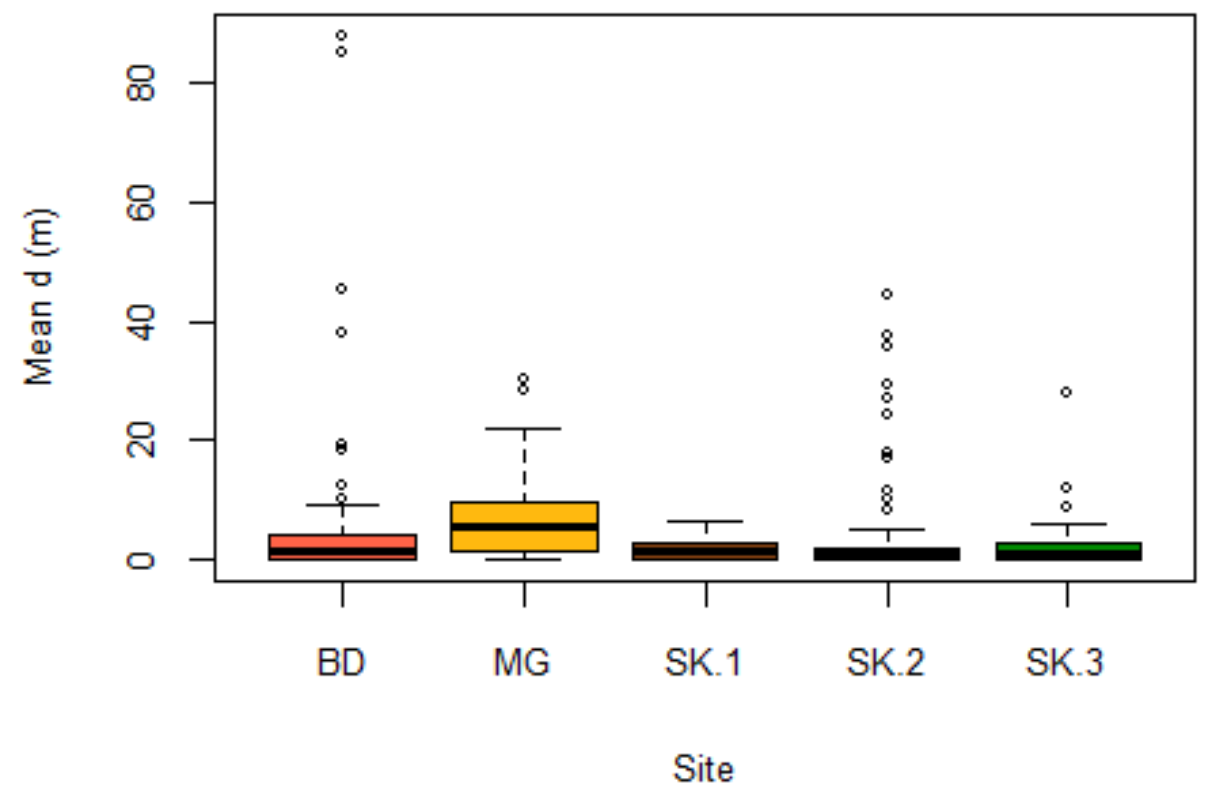

Figure 4. Comparison of $\mathrm{d}$ value means of $D$. spatulifera among five subpopulations, Bido (BD), Mangli (MG), Sokokembang 1 (SK.1), Sokokembang 2 (SK.2), and 
Sokembang 3 (SK.3). Based on the Kruskal Wallis analysis, the mean d value of subpopulations among the sites was different significantly $\left(\mathrm{X}^{2}=19.757, \mathrm{df}=4, \mathrm{p}\right.$ value $<0.001)$. Post Hoc Pairwise Wilcoxon Test shows that Mangli Subpopulation is significantly different from other subpopulations $(\mathrm{P}<0.05)$.

Figure 4 shows that the Subpopulation of Mangli Stream has the highest mean $\mathrm{d}$ and significantly different from other subpopulations. The mean d value of Mangli was $7.51 \mathrm{~m}$. The inner-quartile of mean $\mathrm{d}$ at Bido, Sokokembang 1, Sokokembang 2, and Sokokembang 3 was less than $5 \mathrm{~m}$. The distance movement of Bido, Sokokembang 1, Sokokembang 2, and Sokokembang 3 was quite similar.

The cumulative distance moved of D. spatulifera was short. Out of a total of 302 individuals, there were no single individuals who moved more than 100 meters. Four individuals observed for six weeks seemed to be immobile (Figure 5). Net lifetime movement or the distance between the first and last capture also had a short distance. Dominantly, the distance of net
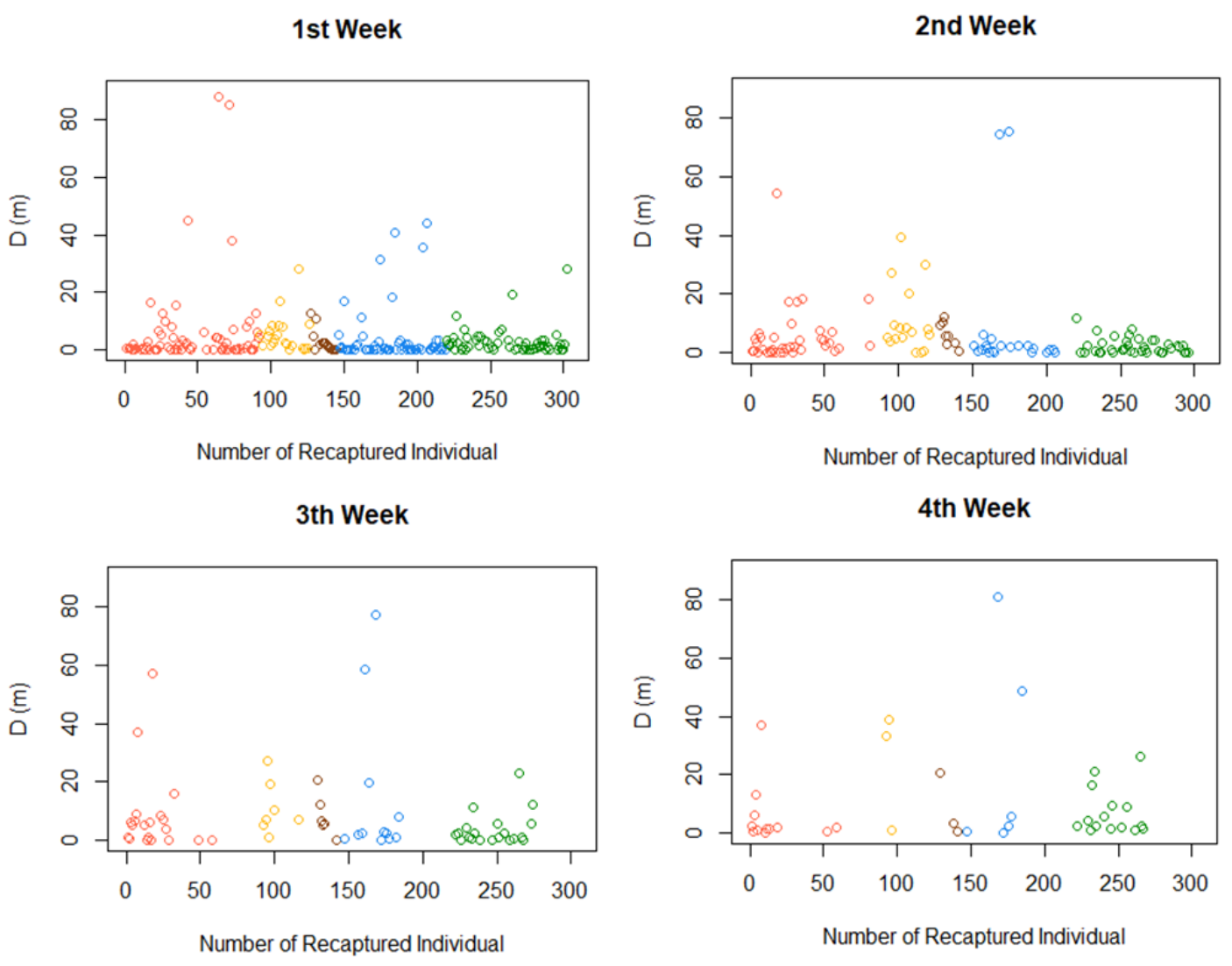

5th week
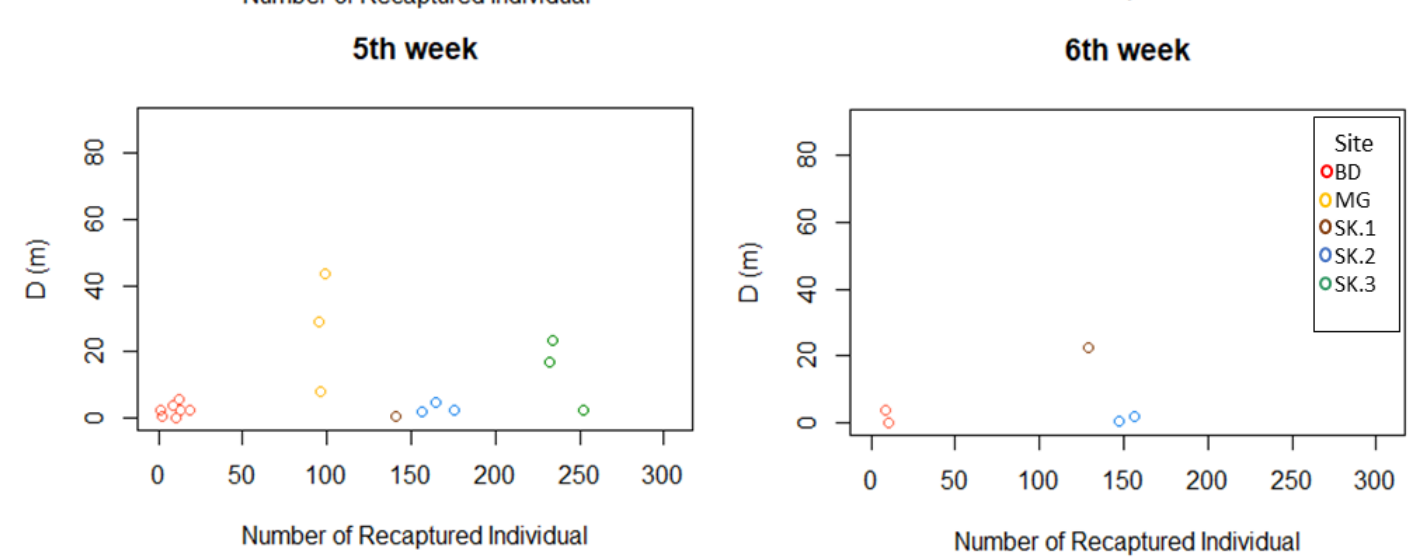

Figure 5. Cumulative Distance Moved (D) of D. spatulifera among the five sites, BD (Bido), MG (Mangli), SK.1 (Sokokembang 1), SK.2 (Sokokembang 2), and SK.3 (Sokembang 3), from the $1^{\text {st }}$ week until 6 ${ }^{\text {th }}$ week. Kruskal Wallis shows that the $\mathrm{D}$ value is significantly different $\left(\mathrm{X}^{2}=19.264\right.$, $\mathrm{df}=4$, $\mathrm{p}$-value $\left.<0.001\right)$. Pairwise Wilcoxon Test shows that the $\mathrm{D}$ value of Mangli is significantly different from Bido, Sokokembang 1, and Sokokembang 3 ( $\mathrm{p}$ value $<0.05$ ). 
lifetime movement was less than $5 \mathrm{~m}(74.83 \%)$. A subpopulation of Mangli had the highest distance of net lifetime movement. The median of net lifetime movement at Bido, Sokokembang 1, Sokokembang 2, and Sokokembang 3 was quite similar (Figure 6). Although the time's duration between the first and last capture varied, the Kendall Correlation score showed that net lifetime movement had a low correlation with the duration of the recapture $(R=0,21 \mathrm{p}$-value $<0.05)$. An increase in the duration of the MRR survey was not followed by an increase in the net age movement.

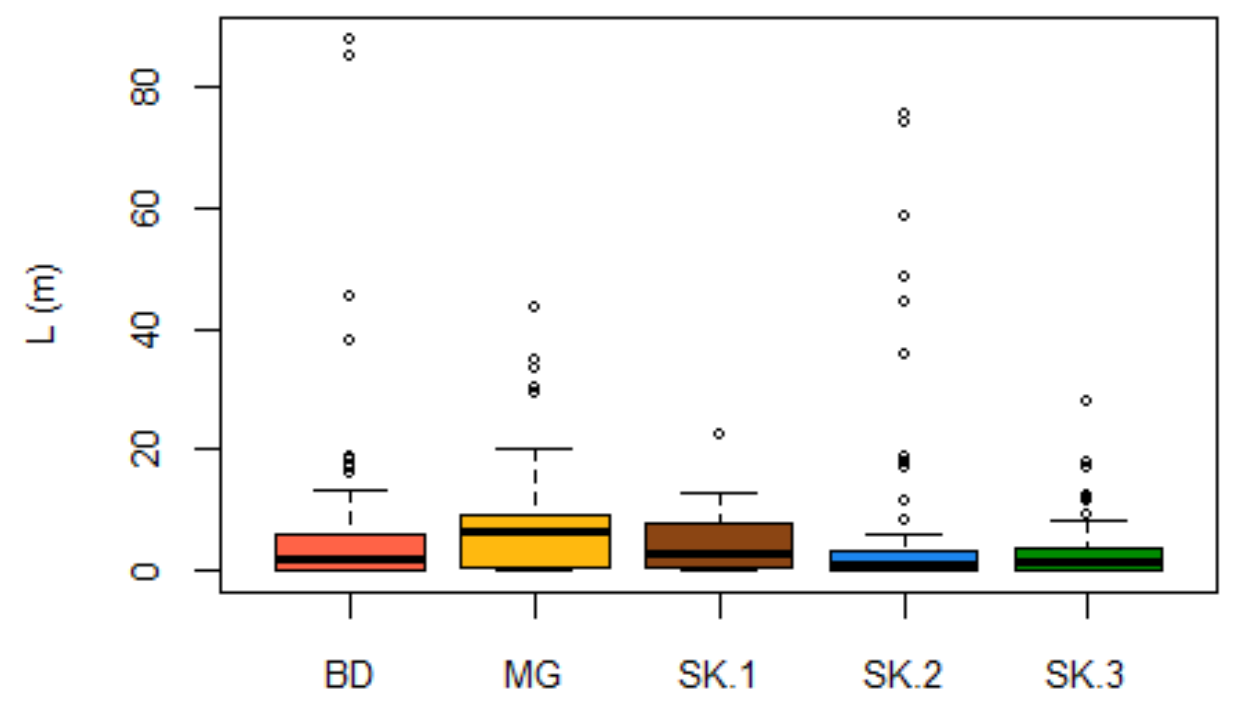

Site

Figure 6. Comparison of net lifetime movement (L) of D. spatulifera among the subpopulations of BD (Bido), MG (Mangli), SK.1 (Sokokembang 1), SK.2 (Sokokembang 2), and SK.3 (Sokembang 3). Kruskal Wallis shows that the net lifetime movement among the subpopulations is significantly different $\left(X^{2}=13.566\right.$, $\mathrm{df}=4$, $\mathrm{p}$-value $<0.05$ ). Pairwise Wilcoxon Test score shows that Mangli is significantly different from Sokokembang 2 and Sokokembang 3 then Bido is significantly different from Sokokembang 3 ( $\mathrm{p}$-value $<0.05$ ).

The subpopulation of Mangli had the farthest dispersal than other subpopulations. Its density was lower than and significantly different from Bido, Sokokembang 2, and Sokokembang 3, indicating the potential of inverse density-dependent (Hixon \& Johnson 2009). Male damselfly encourages further dispersal distances to find female damselfly to mate (Rouquette \& Thompson 2007). However, the inverse density-dependent and dispersal relationship was not significant based on the regression correlation score $\left(\mathrm{r}^{2}=0,094, \mathrm{~F}=2,902 ; \mathrm{P}=0,09957\right)$.

D. spatulifera was found in the dense riparian vegetation dominated by the herbaceous canopy (Table 1). The high density of riparian canopy reflects a good and stable habitat (Samways \& Sharratt 2010). The stable habitat territory of male damselflies is followed by short dispersal behavior (Dolný et al. 2014). The dense riparian cover protect them from predators and direct sunlight (Palacino-Rodríguez et al. 2020). Damselflies avoid direct sunlight due to their body thermoregulation (Heinrich \& Casey 1978; da Silva Monteiro Júnior et al. 2013). It is hard for them to decrease body temperature when the sun's intensity is high (Corbet \& May 2008). Stable habitat territory also provides enough prey for damselflies (Shaw 2020). Therefore, the dispersal of $D$. spatulifera was tended to be stable in each stream. Even more, the density of riparian vegetation in Bido, Mangli, Sokokembang 1 , Sokembang 2 , and Sokokembang 3 was not significantly different. 
The absence of migration or emigration of D. spatulifera among the subpopulations or streams will decrease the cost of dispersal. Short dispersal uses less energy than long dispersal, thereby lowering the probability of death due to migration (Zboralski et al. 2016; Ramakrishnan 2018). Short dispersal distance might be beneficial as bioindicator species. The presence of D. spatulifera in a forest stream represents the quality of stream condition.

Dispersal among subpopulations will influence their persistence and the rate of colonization of vacant patches (Conrad et al. 1999). Nevertheless, there was no strong evidence for the dispersal of D. spatulifera among the subpopulations although the streams among the subpopulations were connected by forest. Therefore, there was no evidence of a metapopulation (Allen \& Thompson 2010) thus colonization and species turnover at vacant patches will not happen (Hanski 2008). In addition, D. spatulifera tends to mate with the same subpopulation. This phenomenon will be followed by the alee effect gradually (Pires \& Duarte Queirós 2019) and increase the potential of extinction (Hanski 2008).

\section{Morphometric Variation of D. spatulifera}

Morphometric variations are the result of the development of organism processes and environmental factors (Hoffmann et al. 2002). The size of the thorax, body, and wings affected the dispersal behavior of damselfly (May 1976; Samejima \& Tsubaki 2010). Therefore, we measured the morphometric variation to support the result of dispersal behavior of $D$. spatulifera among the subpopulations.

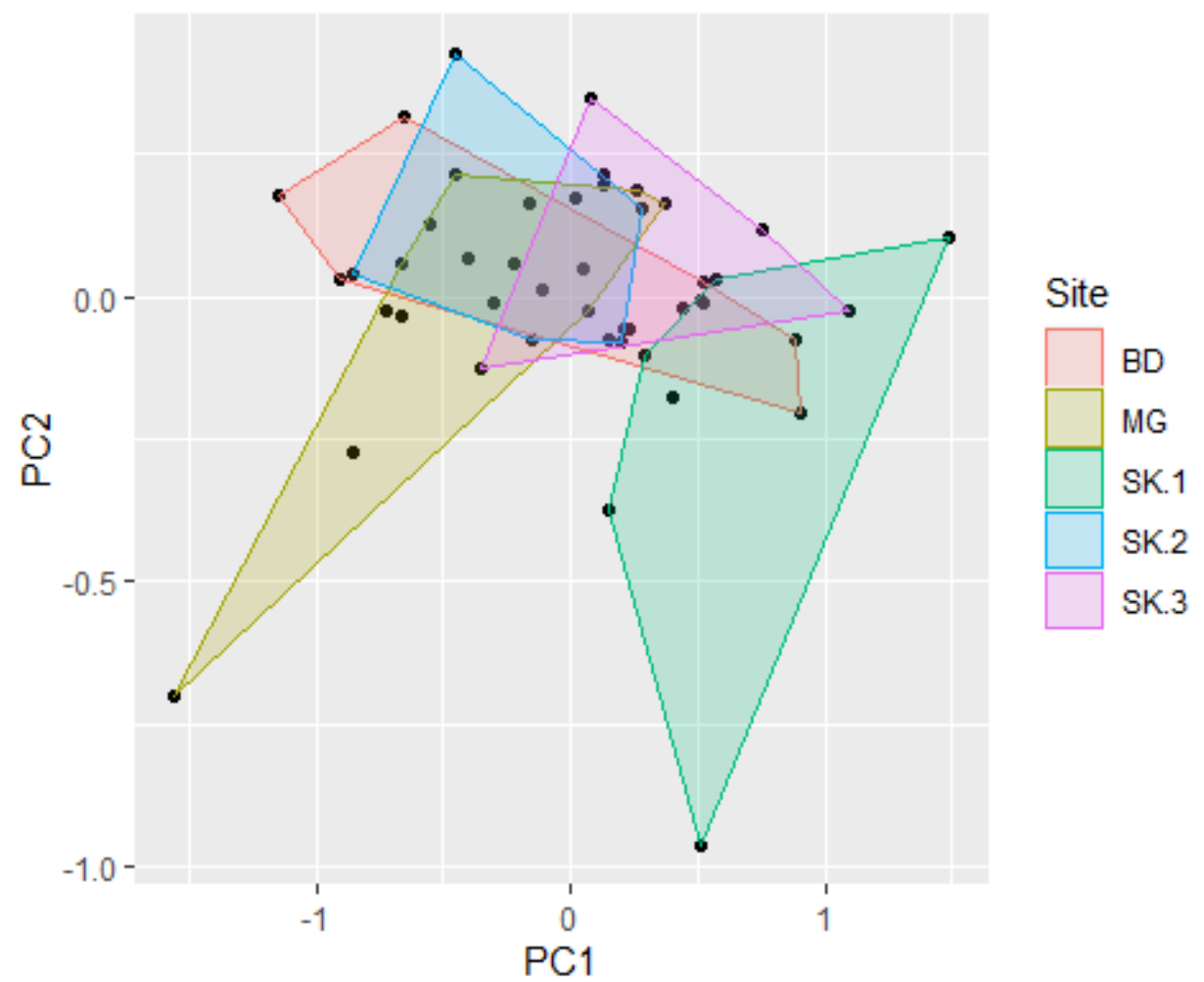

Figure 7. SELF diagram of morphometric variation of $D$. spatulifera among the five sites, namely BD (Bido), MG (Mangli), SK.1 (Sokokembang 1), SK.2 (Sokokembang 2), and SK.3 (Sokembang 3).

Figure 7 shows that morphometric variations among the subpopulations still overlap. Closer subpopulations seem to have quite similar morphometric. The wider overlaps are in Bido, Sokokembang 2, and Sokokembang 3. The distance among the subpopulations affects the degree of variations (Oliveira-Junior et al. 2019). The subpopulations of Bido, 
Sokokembang 3, and Sokokembang 2 were closer than Mangli and Sokokembang 1. It is possible that gene flow is still occurring between these subpopulations although distribution across sites is not observed. On the other hand, Mangli and Sokokembang 1 have their own large and nonoverlapping territory. SELF results confirmed by ANOVA and DMRT are presented in Table 5.

D. spatulifera is a small damselfly. The abdomen and hind wings of D. spatulifera are the shortest compared to other members of the Drepanosticta in Java. The range of body length was only 36.629-37.557 $\mathrm{mm}$ and the abdomen length was 29,813-31.450 mm, slightly larger than the holotype of D. spatulifera from Slamet Mountain (Lieftinck 1929). Based on the 12 continuous morphometric characters, six characters showed significant differences. The subpopulation of Mangli had the longest wings $(\mathrm{RFw}$, RFwNP, RHw, RHwNP) and was significantly different from others. The thorax size (HW, CED, ASD) of Mangli was also greater than others (Table $5)$.

Mangli is far from other subpopulations (Figure 2) since it lies at a higher altitude. The mean temperature of Mangli $\left(24.71^{\circ} \mathrm{C}\right)$ is also lower than Bido, Sokokembang 1, Sokembang 2, and Sokokembang 3 (Table 1). An increase in altitude and a decrease in climate temperature affect an increase in body size (Hagen 2017). Horne et al. (2018) proved that the body size of insects increases along with the additional altitude gradient. Hassall et al., (2008) showed Coenagrion puella (damselfly species) experienced an increase in body size and length of the wing along with the climate temperature gradient.

The microhabitat of Mangli had the lowest herbaceous canopy compared to Bido, Sokokembang 1, Sokokembang 2, and Sokokembang 3. Morphological plasticity was seen in response to habitat. Damselfly that inhabits a more open canopy tended to have larger wing morphology (Taylor \& Merriam 1995). It must have flown farther to reach the herbaceous canopy cover to rest, hide from predators, and avoid direct sunlight (da Silva Monteiro Júnior et al. 2013; Palacino-Rodríguez et al. 2020).

The length of the wing correlates with dispersal capacity (Sacchi \& Hardersen 2013) and occurrence (Rundle et al. 2007). The optimal wings will adjust flight behavior such as foraging and migration (Sacchi \& Hardersen

Table 5. Comparison of the mean and standard deviation of the 12 parameters of $D$. spatulifera morphometric among the five subpopulations.

\begin{tabular}{|c|c|c|c|c|c|c|c|c|c|c|}
\hline \multirow{2}{*}{ Parameter } & \multicolumn{2}{|l|}{$\mathrm{BD}$} & \multicolumn{2}{|l|}{$\mathrm{MG}$} & \multicolumn{2}{|l|}{ SK.1 } & \multicolumn{2}{|l|}{ SK.2 } & \multicolumn{2}{|l|}{ SK.3 } \\
\hline & Mean & SD & Mean & SD & Mean & SD & Mean & SD & Mean & SD \\
\hline BL & 37.152 & 1.789 & 37.221 & 0.899 & 37.577 & 1.008 & 36.629 & 1.324 & 37.509 & 2.218 \\
\hline $\mathrm{AL}^{* *}$ & $29.813^{b}$ & 1.320 & $31.450^{a}$ & 0.942 & $31.817^{\mathrm{a}}$ & 0.885 & $30.755^{a b}$ & 1.081 & $30.835^{\mathrm{ab}}$ & 1.091 \\
\hline $\mathrm{RFw}^{* * *}$ & $19.756^{\mathrm{b}}$ & 0.678 & $21.323^{a}$ & 0.547 & $20.362^{\mathrm{ab}}$ & 0.616 & $20.566 \mathrm{ab}$ & 0.565 & $20.09 \mathrm{~b}$ & 0.681 \\
\hline RFwNP*** & $11.903^{b}$ & 0.502 & $12.882^{\mathrm{a}}$ & 0.374 & $12.370^{\mathrm{ab}}$ & 0.601 & $12.375^{\mathrm{ab}}$ & 0.305 & $12.083^{\mathrm{b}}$ & 0.424 \\
\hline $\mathrm{RHw}^{* * *}$ & $19.548^{\mathrm{b}}$ & 0.604 & $21.101^{a}$ & 0.533 & $20.460^{\mathrm{ab}}$ & 0.505 & $20.429 \mathrm{ab}$ & 0.417 & $19.859^{\mathrm{b}}$ & 0.688 \\
\hline RHwNP*** & $11.240^{c}$ & 0.400 & $12.216^{a}$ & 0.380 & $11.928 \mathrm{ab}$ & 0.423 & $11.644 \mathrm{abc}$ & 0.245 & $11.416^{\mathrm{bc}}$ & 0.422 \\
\hline HW & 3.512 & 0.115 & 3.610 & 0.050 & 3.576 & 0.085 & 3.478 & 0.123 & 3.431 & 0.155 \\
\hline LW & 0.859 & 0.034 & 0.844 & 0.031 & 0.833 & 0.013 & 0.831 & 0.043 & 0.808 & 0.059 \\
\hline CED & 1.647 & 0.061 & 1.674 & 0.042 & 1.663 & 0.078 & 1.635 & 0.043 & 1.602 & 0.059 \\
\hline ASD & 1.028 & 0.030 & 1.080 & 0.077 & 1.030 & 0.019 & 1.022 & 0.062 & 0.998 & 0.052 \\
\hline CL & 0.837 & 0.049 & 0.854 & 0.074 & 0.807 & 0.056 & 0.903 & 0.080 & 0.863 & 0.062 \\
\hline PL* & $0.462^{\mathrm{b}}$ & 0.045 & $0.486^{\mathrm{b}}$ & 0.047 & $0.487 \mathrm{~b}$ & 0.050 & $0.489^{b}$ & 0.058 & $0.538^{a}$ & 0.040 \\
\hline
\end{tabular}




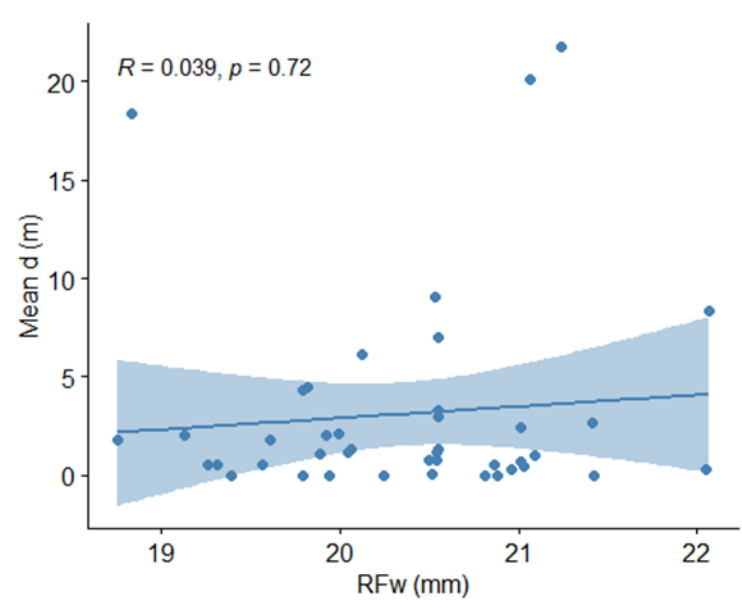

a

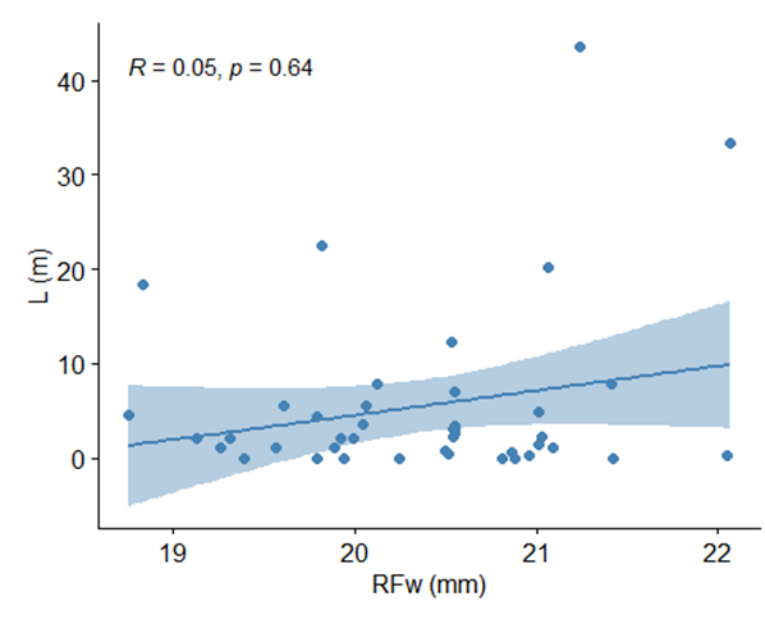

b

Figure 8. Kendal Correlation of Wing Size (the length of right forewing-RFw) with (a) Mean of Distance Moved between Successive Capture (d) and (b) Net Lifetime Movement (L). The relation between wing size and mean d and L is not significant ( $\mathrm{p}$-value $>0.05)$.

2013). Larger male damselflies have more stamina, flight duration, and wing loadings (May 1976; Samejima \& Tsubaki 2010). Larger heads of damselflies have greater thermoregulation and thus have better flight performance (Samejima \& Tsubaki 2010). This case is similar to Enallagma. The larger Enallagma, the more distribution points in North America (Rundle et al. 2007). Individuals of D. spatulifera in Mangli had larger wings and farther distance movement than other sites. However, based on statistical analysis, the correlation of wing size with the distance moved between successive captures and net lifetime movement was still not significant (Figure 8). Possibly, to obtain a significant and strong correlation between wings and individual dispersal, more morphometric samples are needed.

The paraproct parameter of the $D$. spatulifera subpopulation also shows a different pattern (Table 5). The longest length of paraproct is in Sokokembang 3. In Zygoptera, paraproct is one of the determination keys for identifying the Drepanosticta genus (Dow et al. 2018). Paraproct lies at the tip of the abdomen and is paired with cerci. It has trichoid sensilla to hold female prothorax during mating. However, it is still unclear whether the large or small paraproct is more profitable (Suhling et al. 2015).

\section{CONCLUSION}

D. spatulifera has a short movement and low dispersal distance. The variation of distance moved between successive capture and wing size from Mangli's subpopulation was significantly different from the other sites. In the Mangli subpopulation, the farther and higher the altitude of the site, the farther the movement, the more dispersed, and the larger the wing size of D. spatulifera. Closer subpopulations were less likely to show significant differences in the dispersal and morphometric variations. Our study shows that $D$. spatulifera is an extremely sedentary species. It means that $D$. spatulifera is a good flagship species to represent the forest stream condition. However, it has been threatened due to its high potential of inbreeding, thereby decreasing its fitness and vulnerability to extinction. Furthermore, it is necessary to study the interaction among the subpopulations of D. spatulifera in Petungkriyono Forest. This will provide information on the rescue effect and turnover phenomenon of the D. spatulifera population. It can also classify the group of subpopulations as local population or metapopulation. In the end, it can show the conservation ways for D. spatulifera and the forest habitat. 


\section{AUTHORS CONTRIBUTION}

A.N. and R.C.H.S designed the research. AN collected and analysed the data, and wrote the manuscript. R.C.H.S reviewed, revised, proofread the final manuscript, and supervised the process.

\section{ACKNOWLEDGMENTS}

We deliver our gratitude to Tariyo and Rasdi for their contribution and support in field data collection. We are also grateful to LPDP for funding this research and Universitas Gadjah Mada for supporting this research. Finally, we thank the reviewers and editors for their constructive comments and reviews.

\section{CONFLICT OF INTEREST}

We confirm that there is no conflict of interest associated with this publication.

\section{REFERENCES}

Allen, K.A. \& Thompson, D.J., 2010. Movement characteristics of the Scarce Blue-tailed Damselfly, Ischnura pumilio. Insect Conservation and Diversity, 3(1), pp.5-14.

Conrad, K.F. et al., 1999. Dispersal characteristics of seven odonate species in an agricultural landscape. Ecography, 22(5), pp.524-531.

Corbet, P.S. \& May, M.L., 2008. Fliers and perchers among Odonata: Dichotomy or multidimensional continuum? A provisional reappraisal. International Journal of Odonatology, 11(2), pp.155-171.

da Silva Monteiro Júnior, C. et al., 2013. Effect of vegetation removal for road building on richness and composition of Odonata communities in Amazonia, Brazil. International Journal of Odonatology, 16(2), pp.135-144.

Diniarsih, S., 2016, 'Endemik jawa anggota genus Drepanosticta (Odonata: Platystictidae)', Thesis, Universitas Gadjah Mada.

Dolný, A., Harabiš, F. \& Mižičová, H., 2014. Home range, movement, and distribution patterns of the threatened dragonfly Sympetrum depressiusculum (Odonata: Libellulidae): A thousand times greater territory to protect? PLOS ONE, 9(7), e100408.

Dow, R. A., 2009. Drepanosticta spatulifera. The IUCN Red List of Threatened Species 2009, e.T163820A5656272.

Dow, R.A., Kompier, T. \& Phan, Q.T., 2018. Drepanosticta emtrai sp. nov. from Vietnam with a discussion of Drepanosticta vietnamica Asahina, 1997 (Odonata: Zygoptera: Platystictidae). Zootaxa, 4374(2), pp.273282.

Gibert, J.P., 2016. The effect of phenotypic variation on metapopulation persistence. Population Ecology, 58(3), pp.345-355.

Gyulavári, H.A. et al., 2011. Morphometric and molecular studies on the populations of the damselflies Chalcolestes viridis and C. parvidens (Odonata, Lestidae). International Journal of Odonatology, 14(4), pp.329339.

Hagen, J.B., 2017. Bergmann's Rule, Adaptation, and Thermoregulation in Arctic Animals: Conflicting Perspectives from Physiology, Evolutionary Biology, and Physical Anthropology After World War II. Journal of the History of Biology, 50(2), pp.235-265.

Hanski, I., 2008. Metapopulation Models. Encyclopedia of Ecology, Five-Volume Set, (2000), pp.2318-2325.

Hassall, C. \& Thompson, D.J., 2012. Study design and mark-recapture estimates of dispersal: A case study with the endangered damselfly Coenagrion mercuriale. Journal of Insect Conservation, 16(1), pp.111-120. 
Hassall, C., Thompson, D.J. \& Harvey, I.F., 2008. Latitudinal variation in morphology in two sympatric damselfly species with contrasting range dynamics (Odonata: Coenagrionidae). European Journal of Entomology, 105(5), pp.939-944.

Heinrich, B.Y.B. \& Casey, T.M., 1978. Heat Transfer in Dragonflies: 'Fliers' and 'Perchers.' Journal of Experimental Biology, 74(1), pp.17-36.

Hixon, M.A. \& Johnson, D.W., 2009, 'Density Dependence and Independence', Encyclopedia of Life Sciences, John Wiley \& Sons, Ltd: Chichester.

Hoffmann, A.A., Collins, E. \& Woods, R., 2002. Wing shape and wing size changes as indicators of environmental stress in Helicoverpa punctigera (Lepidoptera: Noctuidae) moths: Comparing shifts in means, variances, and asymmetries. Environmental Entomology, 31(6), pp.965-971.

Horne, C.R., Hirst, A.G. \& Atkinson, D., 2018. Insect temperature-body size trends common to laboratory, latitudinal and seasonal gradients are not found across altitudes. Functional Ecology, 32(4), pp.948-957.

Kalkman, V. \& A. Orr. 2013. Field guide to the damselflies of New Guinea. Brachytron, 16, pp.3-120.

Keller, D. \& Holderegger, R., 2013. Damselflies use different movement strategies for short- and long-distance dispersal. Insect Conservation and Diversity, 6(5), pp.590-597.

La Porta, G. \& Goretti, E., 2020. Movement and demography of Southern damselfly (Coenagrion mercuriale, Odonata) in a Mediterranean lotic ecosystem. Ethology Ecology and Evolution, 32(2), pp.107-121.

Lieftinck, M.A., 1929, 'Contributions to the Dragonfly fauna of the Sondaic Area', in Odonata, J.T. \& C.H. De Meijere, Tijdschrift Voor Entomologie, De Nederlandsche Entomologische Vereeniging, pp.110-115, Tweede Aflevering.

May, M.L., 1976. Thermoregulation and Adaptation to Temperature in Dragonflies (Odonata: Anisoptera). Ecological Monographs, 46(1), pp.132.

McCauley, S.J., 2013. Relationship between morphology, dispersal and habitat distribution in three species of Libellula (Odonata: Anisoptera). Aquatic Insects, 34(3-4), pp.195-204.

Nugrahaningrum, A., 2018, 'Fluktuasi populasi capung jarum Drepanosticta spatulifera Lieftinck, 1929, endemik jawa (Odonata: Platystictidae) di aliran sungai Hutan Lindung Petungkriyono, Pekalongan, Jawa Tengah', Undergraduate Thesis, Universitas Gadjah Mada.

O’Dell, R.E. \& Rajakaruna, N., 2011, 'Intraspecific variation, Adaptation, and Evolution', in S. Harrison (eds.), Serpentine: The Evolution and Ecology of a Model System, pp.97-138, California Scholarship Online.

Oliveira-Junior, J.M.B. et al., 2019. The response of neotropical dragonflies (Insecta: Odonata) to local and regional abiotic factors in small streams of the amazon. Insects, 10(12).

Palacino-Rodríguez, F. et al., 2020. Effects of seasonality and environmental change on an Andean damselfly Mesamphiagrion laterale (Odonata: Coenagrionidae). Journal of Insect Conservation, 24(3), pp.499-511.

Pires, M.A. \& Duarte Queirós, S.M., 2019. Optimal dispersal in ecological dynamics with Allee effect in metapopulations. PLoS ONE, 14(6), e0218087.

Ramakrishnan, A.P., 2018. Dispersal-Migration. Encyclopedia of Ecology, 1, pp.185-191.

Rouquette, J.R. \& Thompson, D.J., 2007. Patterns of movement and dispersal in an endangered damselfly and the consequences for its management. Journal of Applied Ecology, 44(3), pp.692-701. 
Rundle, S.D. et al., 2007. Range size in North American Enallagma damselflies correlates with wing size. Freshwater Biology, 52(3), pp.471477.

Sacchi, R. \& Hardersen, S., 2013. Wing length allometry in Odonata: Differences between families in relation to migratory behaviour. Zoomorphology, 132(1), pp.23-32.

Samejima, Y. \& Tsubaki, Y., 2010. Body temperature and body size affect flight performance in a damselfly. Behavioral Ecology and Sociobiology, 64 (4), pp.685-692.

Samways, M.J. \& Sharratt, N.J., 2010. Recovery of endemic dragonflies after removal of invasive alien trees: Contributed paper. Conservation Biology, 24(1), pp.267-277.

Shaw, A.K., 2020. Causes and consequences of individual variation in animal movement. Movement Ecology, 8(1), pp.1-12.

Suhling, F. et al., 2015. Order Odonata Fourth Edi., Elsevier.

Suhonen, J. et al., 2010. Local extinction of dragonfly and damselfly populations in low- and high-quality habitat patches. Conservation Biology, 24(4), pp.1148-1153.

Taylor, P.D. \& Merriam, G., 1995. Wing Morphology of a Forest Damselfly Is Related to Landscape Structure. Oikos, 73, pp.43-48.

van Tol, J., 2009, Phylogeny and biogeography of the Platystictidae (Odonata), Ph.D. Thesis, University of Leiden.

Zaman, M.N., Fuadi, B.F. \& Sultoni, A., 2019. Diversity of Dragonfly Genus Drepanosticta in Tourism Forest Curug. Proceeding International Conference Science Engineering, 2, pp.115-118.

Zboralski, A. et al., 2016. Density-dependent dispersal in biological control agents: a reflexion on the side-effects of mass-rearing conditions. BioControl, 61(1), pp.13-22.

Zebsa, R., Khelifa, R. \& Kahalerras, A., 2015. Adult movement pattern and habitat preferences of the maghribian endemic gomphus lucasii (odonata: Gomphidae). Journal of Insect Science, 15(1), pp.1-8. 